International Journal of Social Science And Human Research

ISSN(print): 2644-0679, ISSN(online): 2644-0695

Volume 05 Issue 01 January 2022

DOI: 10.47191/ijsshr/v5-i1-46, Impact factor-5.586

Page No: $333-336$

\title{
The Role of Strategic Diplomacy in the National Nuclear Power Plant Development Plan in Indonesia in Supporting Energy and National Defense
}

\author{
Krisna Surya Narindra ${ }^{1}$, Sudibyo ${ }^{2}$, Lukman Yudho Prakoso ${ }^{3}$ \\ ${ }^{1,2,3}$ Indonesia Defense University
}

\begin{abstract}
Energy diplomacy as a country's foreign policy agenda in securing access to international energy sources. The significance of energy for a country can always be a cause or proxy for its foreign policy or even its military actions. The plan for the development of nuclear power plants in Indonesia in support of the climate change program is based on global agreements and is able to provide a deterrent effect on national defense. However, until now the role of defense diplomacy in achieving national interests has not been optimal and its achievements are still limited to defense issues only (Sudarsono et al., 2018). This study aims to analyze the role of diplomacy on energy and defense, where diplomacy provides a first treat on energy, thereby realizing national energy security supported by defense diplomacy. This study uses a literature study to collect relevant data related to energy diplomacy, nuclear power plant development plans to support the NDC program, and defense diplomacy. The results of the study indicate that a diplomacy synergy is needed in achieving the national interest. Defense diplomacy can be synergized with energy diplomacy, which in this case is able to accelerate the development of nuclear power plants in Indonesia which provides a multiplier effect both in terms of energy security in the issue of climate change, even to the deterrent effect of Indonesian defense. The effect of diplomacy on energy indicates that diplomacy has a significant role in politics and the economy that a country's energy can create.
\end{abstract}

KEYWORDS: Diplomacy, Energy, Defense, Climate Change

\section{INTRODUCTION}

Energy diplomacy can be regarded as one of the foreign policy agendas of a country aimed at securing access to international energy sources. Consumption of international energy that has never decreased, while the availability of resources from that energy is limited, it is necessary to coordinate between countries to manage and regulate international energy use through diplomacy, especially in the current multilateral international system. Through international energy diplomacy in the multilateral era, countries hope to be able to maintain their energy supply in order to fulfill their national interests (Kusumawardani, 2019).

The issue of climate change has driven multilateral diplomacy between countries in the world to overcome this. Global policy at the High-Level Conference of the Parties, 'Conference of the Parties' (COP26) on World Climate Change, 'United Nations Framework Convention on Climate Change' (UNFCCC) on 13 November 2021 resulted in a number of important decisions including including political affirmation of leaders and representatives of state parties that anthropogenic activities have resulted in a temperature increase of approximately $1,1^{\circ} \mathrm{C}$ whose impacts are already being felt worldwide. The implication is that emergency measures and efforts to deal with climate change in terms of mitigation, adaptation, and funding need attention. Political support and escort of the Indonesian Parliament to encourage public budgets and government climate diplomacy are important factors in fulfilling Indonesia's NDC commitments. The issue of funding to meet NDC commitments is, of course, a formidable challenge due to the large demand and the projected high funding needs, worth US\$322.86 billion (Rp4,520 trillion) that the government needs to prepare. A number of things need to be targeted by the government to meet these funding needs (Hariyadi, 2021).

In Indonesia's national energy policy, the target for the NRE mix is 23\% in 2025 and 31\% in 2050 as stated in PP no. 79 of 2014 and Presidential Decree No. 22 of 2017 concerning RUEN. To achieve the target of 23\% NRE in the national energy mix in 2025 will be difficult to achieve without the role of nuclear power plants. In addition, it is also a form of commitment in the Paris Agreement which is contained in Law No. 16 of 2016 which maintains an increase in the earth's temperature by $2^{\circ} \mathrm{C}$.

Nuclear is a type of energy that has a multiplier effect on all national strategic sectors. One of the urgencies for the development of a Nuclear Power Plant (NPP) in Indonesia is the energy deficit that still occurs in West Kalimantan, until now the power supply of $230 \mathrm{MW}$ is obtained from SESCO Sarawak Malaysia, which operates $100 \mathrm{MW}$ at base load and an additional $130 \mathrm{MW}$ at at peak load. The condition of a shortage of electricity supply in the Frontier, Remote and Disadvantaged (3T) areas at the border can 


\section{The Role of Strategic Diplomacy in the National Nuclear Power Plant Development Plan in Indonesia in Supporting Energy and National Defense}

potentially be a military and non-military threat, which includes the ideological, political, economic, socio-cultural, defense and security aspects (Alwi, 2007).

This then indicates that the significance of energy for a country can almost always be a cause or proxy for its foreign policy or even military action. The influence of energy in diplomacy between countries indicates that energy has a very significant role in the politics and economy of a country. The importance of energy for the survival of a country can be explained through several reasons, such as; First, energy is more important to the economic and social development of the modern world than any other good or commodity; Second, hydrocarbon resources are distributed unequally in the world; and third, energy trade is often associated with the permanent infrastructure needed for the transportation of hydrocarbons and electricity, especially for industrialized countries (Selivanova, 2010: 49).

\section{RESEARCH METHOD}

This study uses a literature study to collect relevant data related to energy diplomacy, nuclear power plant development plans to support the NDC program, and defense diplomacy. The reference data obtained were processed in a qualitative descriptive manner.

\section{DISCUSSION}

The importance of energy for the survival of a country can be explained through several reasons, such as; First, energy is more important to the economic and social development of the modern world than any other good or commodity; Second, hydrocarbon resources are distributed unequally in the world; and third, energy trade is often associated with the permanent infrastructure needed for the transportation of hydrocarbons and electricity, especially for industrialized countries (Selivanova, 2010).

The plan to develop nuclear power plants in Indonesia is inseparable from the issue of climate change, which is a global concern and has an impact on Indonesia's national policies. We also need to realize that the implementation of nuclear power plant development also requires no small amount of money. The role of diplomacy is very much needed in realizing the development of nuclear power plants in Indonesia, both in terms of NDC funding in the issue of climate change through the development of new and renewable energy (including nuclear power plants), investment in nuclear power plant development, to defense diplomacy as a relay for the impact of energy diplomacy. The construction of nuclear power plants in the West Kalimantan region will change the defense aspect in maintaining vital national objects. As a border region. West Kalimantan faces a real threat that can endanger the National Obstetrics and Safety Committee. Cooperation involving various layers, both national and international, in the use of nuclear technology for peaceful purposes, needs to be continuously campaigned so that it can provide direct benefits for national development and people's welfare. This is in line with the vision of the national foreign policy proclaimed by the Government of Indonesia. Bilateral and multilateral diplomacy is directed at providing a concrete and direct impact on the community in the form of increasing the level of the economy and supporting various strategic sectors of national development.

Nuclear power plant as a new type of renewable energy which is included in the target of fulfilling the NDC commitment also requires efforts to implement its development in Indonesia. In terms of funding issues, meeting NDC commitments is of course a formidable challenge due to the large demand and the projected high funding needs, amounting to US $\$ 322.86$ billion (Rp4,520 trillion) which the government needs to prepare. A number of things need to be targeted by the government to meet these funding needs. First, strengthening the support base for public funding and funding breakthroughs through other sources. Second, strengthening BPDLH to enforce governance and institutional credibility. Third, mobilize carbon tax funds. Political support and escort of the Indonesian Parliament to ensure the increasing sources of public funding and the success of the government's climate diplomacy to suppress the fulfillment of the promises of developed countries are important factors in achieving Indonesia's NDC implementation (Hariyadi, 2021).

In addition to nuclear power plants being a climate change issue in maintaining the increase in earth's temperature, there has been a paradigm shift in the use of nuclear in line with the expansion of the security concept. Previously, nuclear was understood only in a narrow (traditional) security context, namely for weapons purposes. Now nuclear applications are being developed in a broader context, namely a wider (nontraditional) security scope, namely to build various strategic sectors such as food security, energy security and a stronger economic foundation. Furthermore, Ambassador Djumala conveyed Indonesia's active role in carrying out nuclear cooperation diplomacy as a member of the International Atomic Energy Agency (IAEA). Through a down-to-earth diplomatic approach, Indonesia encourages IAEA cooperation with its member countries to be able to answer real challenges in various development sectors at the national level. The role of Indonesia's leadership in the capacity of the Chair of the IAEA Board of Governors in 2017-2018 has had a real impact on strengthening technical cooperation in nuclear applications, which has a much larger priority share than other IAEA technical programs that are supervisory in nature.

The plan to develop nuclear power plants in the West Kalimantan region is a strategic issue, where nuclear power plants, which will become a vital national object, have new potential and challenges for the dynamics of defense strategy. This makes the performance of defense forces in West Kalimantan must be reviewed and improved. The nuclear power plant will become a vital 
national object (obvitnas) with a dangerous strategic value on the basis of potential threats and safety hazards to space and the public (Alfarasyi \& N, 2019).

Article 7 of Law Number 34 of 2004 concerning the Indonesian National Armed Forces explains that the main task of the TNI is to secure strategic national vital objects. Protect against sabotage from certain parties that damage important installations and national vital objects. The national vital objects in question are those that are strategic in nature concerning the lives of many people, the dignity and worth of the nation, as well as national interests determined by government decisions. Security of National Vital Objects is carried out to prevent increasing threats and disturbances to National Vital Objects including acts of terrorism. Defense diplomacy according to Cottey and Foster is defined as the use of the armed forces and the Ministry of Defense in times of peace as a tool for foreign policy and defense policy, particularly for military cooperation and assistance (Sari, 2020.)

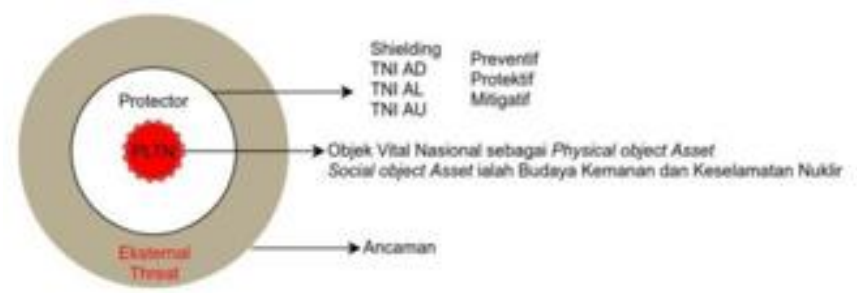

Figure. 1. Defense System against Obvitnas NPP

Source: Alfarasyi \& N, 2019

Morgan explained that deterrence itself is a military strategy by taking prevention in a formal frontal war through the possession of nuclear weapons of mass destruction (Morgan, 2003). Back to Art's thinking, which explains that in carrying out a deterrence, there are certain conditions that must be owned by these countries (Art, 2009). The second condition is the ability of a country regarding its second- strike capacity. Second strike capabilities include the ground forces, namely the nuclear land base, the air force, namely fighter aircraft that are possible or can transport and launch nuclear weapons, and finally the navy, namely submarines with nuclear weapons capabilities (Morgan, 2003). With strength in these three aspects, it is hoped that the country will have a means of retaliation that can be feared if other countries choose to attack, in other words, that is to take precautions by showing their capabilities. After that, the third condition in deterrence theory is that the countries concerned may not even be involved in an armed conflict directly (Art, 2009). The direct involvement of each country in armed conflict can be a factor that makes it easier for both of them to make conflict decisions for the umpteenth time in the future for both countries.

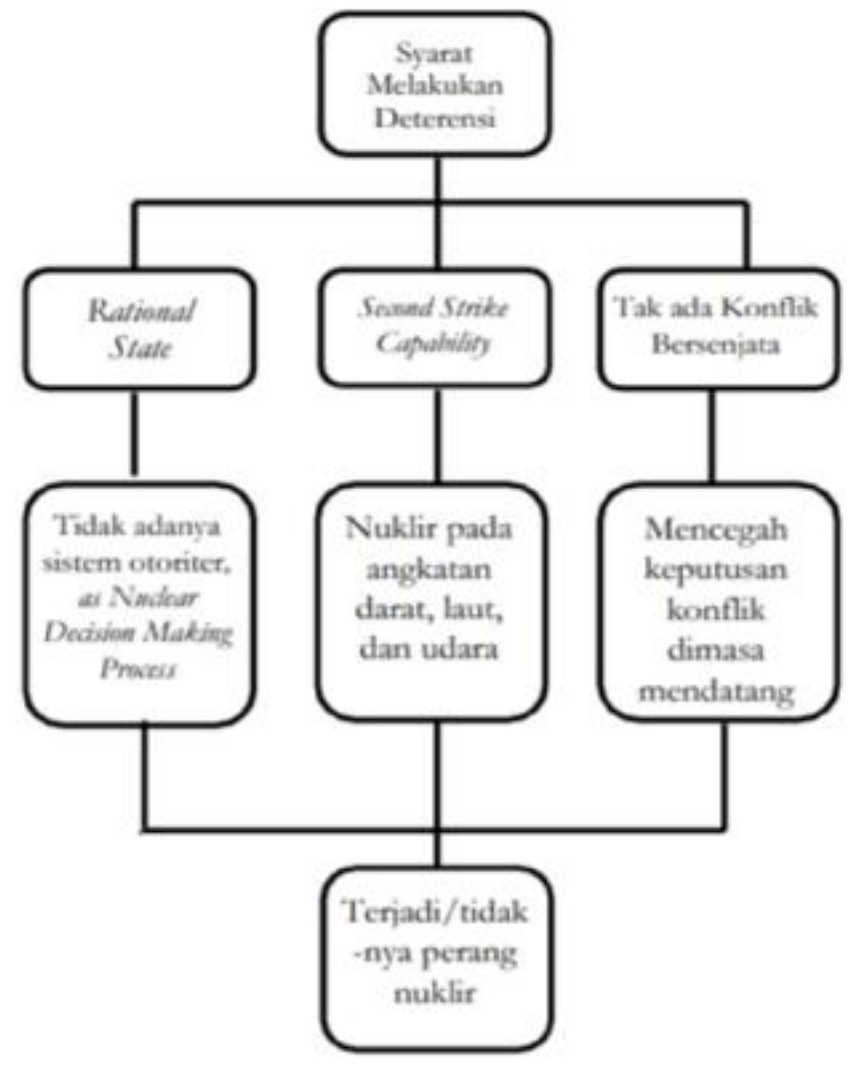

Figure 2. Indicators of Detergent Requirements of a Country

Source: Fajria (2018) 


\section{The Role of Strategic Diplomacy in the National Nuclear Power Plant Development Plan in Indonesia in Supporting Energy and National Defense}

The role of defense diplomacy in achieving national interests has not been optimal and its achievements are still limited to mere defense issues (Sudarsono et al., 2018). Total diplomacy should address the objectives of securing energy supply, accessing markets and outward investment, as well as ensuring the sustainable transformation of primary energy sources from fossil to renewable energy. Total diplomacy of Indonesia's energy sector will be supported through three activities: knowledge production, stakeholder engagement, and new public diplomacy (Winanti et al., 2020). Therefore, a diplomatic synergy is needed in achieving Indonesia's sustainable development. Defense diplomacy can be synergized with energy diplomacy, which in this case is able to accelerate the development of nuclear power plants in Indonesia which provides a multiplier effect both in terms of energy security in the issue of climate change, even to the deterrent effect of Indonesian defense. Diplomacy has a very significant role in energy and defense, where diplomacy provides a first treat on energy, thereby realizing national energy security. Furthermore, they are able to analyze defense diplomacy as a result of energy diplomacy.

\section{CONCLUSIONS}

The researcher recommends that further the role of defense diplomacy in achieving national interests is not optimal and its achievements are still limited to defense issues (Sudarsono et al., 2018). Therefore, a diplomatic synergy is needed in achieving Indonesia's sustainable development. Defense diplomacy can be synergized with energy diplomacy, which in this case is able to accelerate the development of nuclear power plants in Indonesia which provides a multiplier effect both in terms of energy security in the issue of climate change, even to the deterrent effect of Indonesian defense.

\section{REFERENCES}

1) Alfarasyi, A. R., \& N, D. A. N. (2019). Kajian Aspek Pertahanan dalam mendukung Pembangunan PLTN di Kalimantan Barat. Prosiding Seminar Nasional Infrastruktur Energi Nuklir, 31-38.

2) Alwi, A. (2007). Analisis Pelayanan PT. PLN (Persero) Wilayah Kalbar dan Dampak Ekonomi, Sosial Budaya, Pertahanan dan Keamanan Akibat Program Pembelian Energi Listrik Dari SESCO Sarawak Untuk Daerah Perbatasan di Kalimantan Barat. Jurnal Sains Pemasaran Indonesia, VI/3, 277-300.

3) Art, R. J. (2009) The Political Use of Force: The Four Function of Force dalam R. Art, \& R. Jervis, International Politics: Enduring Concepts and Contemporary Issues, 9th ed, New York: Pearson Education.

4) Fajria, R. (2018). Menilai Potensi Perang dibalik Kepemilikan Nuklir India dan Pakistan. Nation State: Journal of International Studies, 1(1).

5) Hariyadi. (2021). Tekanan Pendanaan Implementasi Nationally Determined Contribution (NDC) Indonesia Pasca-Pakta Glasglow. Pusat Penelitian Badan Keahlian DPR RI Bidang Ekonomi Dan Kebijakan Publik, XIII (23), 19-25.

6) Kusumawardani, Damar. 2019. Diplomasi Energi di Era Multilateral: Mekanisme, Tantangan dan Alternatif. http://damarkusumawardani-fisip15.web.unair.ac.id/ diakses 24 Januari 2022.

7) Sari, M. I. (2020). Implementasi Diplomasi Pertahanan Indonesia di Masa Pandemi COVID-19. 21.

8) Selivanova, Yulia. 2010. "Managing the Patchwork of Agreements in Trade and Investment", dalam Adreas Goldthau dan Jan Martin Witte (eds.), Global Energy Governance: The New Rules of The Game. Washington DC: Brookings Institution Press. Ch. 3, pp. 49-72.

9) Sudarsono, B. P., Mahroza, J., \& D.W., S. (2018). Diplomasi Pertahanan Indonesia dalam mencapai Kepentingan Nasional. Jurnal Pertahanan \& Bela Negara, 8(December 2018). https://doi.org/10.33172/jpbh.v8i3.441.

10) Winanti, P., Mada, U. G., Rum, M., Mada, U. G., Nandyatama, R., \& Mada, U. G. (2020). Diplomasi Energi Indonesia. March. https://doi.org/10.6084/m9.figshare.12030381. 